\title{
Solusi Peningkatan Sumberdaya Manusia Pada Baytul Maal wat Tamwil (BMT) di Indonesia Melalui Pendekatan Analytic Network Process (ANP)
}

\section{The Solution of Human Resources Development for Baytul Maal wat Tamwil (BMT) in Indonesia: an Analytic Network Process (ANP) Approach}

\author{
${ }^{1}$ Fiqih Apriadi, ${ }^{2}$ Muhammad Findi A \\ ${ }^{1}$ Alumnus Sarjana Ekonomi Islam (S.E.I.) STEI Tazkia Bogor* \\ ${ }^{2}$ Dosen FEM IPB dan Peneliti Pusat Studi Bisnis dan Ekonomi Syariah/ CIBESt IPB**
}

\begin{abstract}
Baitul Maal wat Tamwil (BMT), as a micro financial institution, has a strategic role in Indonsia. The lack in quality of human resources has been a challenge since its establishment. This issue still needs to be considered seriously. Therefore, this study tries to examine the internal problems regarding the BMT human resources in Indonesia. Analytic Network Process (ANP) is used as the methodology to overcome the objective of this study. Survey and indepth interview are conducted to collect the data. The results showed that the main problems occurred in human resource management were when it dealt with training and skill development programs. Moreover, ethics and morality of the employees needs to be improved continuosly as part of the worship to Allah SWT.
\end{abstract}

Keywords. Analytic Network Process, BMT, Human Resources

\begin{abstract}
Abstrak. Baitul Maal wat Tamwil (BMT) sebagai lembaga keuangan mikro syariah memiliki peran yang sangat strategis di Indonesia. Akan tetapi dalam perjalanannya tidak sedikit kendala dan permasalahan yang harus dihadapi, diantaranya yang paling perlu mendapat perhatian adalah masalah rendahnya mutu Sumberdaya Manusia (SdM). Penelitian ini bertujuan untuk mengetahui apa saja permasalahan internal yang dihadapi BMT di Indonesia. Metodologi yang digunakan dalam penelitian ini adalah metodologi kualitatif analytic network process (ANP). Hasil dari wawancara dan indepth interview dengan responden, menunjukkan bahwa permasalahan dari aspek internal sumberdaya manusia yang perlu segera diperbaiki adalah unsur peningkatan pelatihan dan keterampilan kerja para pekerja atau profesionsal BMT. Disamping aspek keterampilan kerja, aspek moral/akhlak pekerja juga perlu dijaga dan ditingkatkan secara terus menerus dengan penuh kesabaran, sebagai bentuk ketaatan kepada Allah SWT.
\end{abstract}

Kata Kunci: BMT, Sumberdaya Manusia, Analytic network process 


\section{Pendahuluan}

Baitul Maal wat Tamwil (BMT) sebagai lembaga keuangan mikro syariah (LKMS) memiliki peran yang sangat strategis dalam perkembangan ekonomi syariah di Indonesia. Setidaknya ada lima alasan mengenai hal tersebut, yaitu alasan kondisi sosial ekonomi, alasan sejarah, alasan momentum, alasan ideologis dan alasan potensi.

Alasan yang pertama adalah alasan kondisi sosial ekonomi di Indonesia. Kondisi perekonomian di Indonesia saat ini didominasi oleh usaha mikro, kecil dan menengah seperti dapat dilihat pada tabel berikut.

Tabel 1 Perkembangan Data Usaha Mikro, Kecil, Menengah (UMKM) Tahun 2006 - 2010

\begin{tabular}{|l|l|c|c|c|c|c|}
\hline No & \multicolumn{1}{|c|}{ Indikator } & $\begin{array}{c}\text { Tahun } \\
2006\end{array}$ & $\begin{array}{c}\text { Tahun } \\
2007\end{array}$ & $\begin{array}{c}\text { Tahun } \\
2008\end{array}$ & $\begin{array}{c}\text { Tahun } \\
2009\end{array}$ & $\begin{array}{c}\text { Tahun } \\
2010\end{array}$ \\
\hline 1 & Unit usaha (\%) & 99,99 & 99,99 & 99,99 & 99,99 & 99,99 \\
\hline 2 & $\begin{array}{l}\text { Tenaga kerja } \\
(\%)\end{array}$ & 97,3 & 97,27 & 97,15 & 97,3 & 97,22 \\
\hline 3 & PDB (\%) & 56,23 & 56,28 & 55,67 & 56,53 & 57,12 \\
\hline
\end{tabular}

Sumber: Kemenkop dan UKM RI, 2011 (diolah)

Dari data di atas dapat dilihat bahwa usaha mikro, kecil dan menengah merupakan usaha yang paling mendominasi baik dari sisi unit usaha, tenaga kerja ataupun kontribusi terhadap PDB. Namun di sisi lain, bank sebagai lembaga keuangan utama di Indonesia memiliki realitas sebagai berikut :

- Rata-rata LDR (Loan to Deposit Rasio, dana tabungan yang disalurkan sebagai kredit) dari lebih 1000 triliyun aset perbankan nasional nilainya kurang dari 60\%, selebihnya disimpan di BI sebagai SBI yang hanya dengan disimpan sudah mendapatkan bunga.

- Komposisi kredit yang disalurkan (berdasar penelitian BI) :

1. Nilai Rp 5 milyar ke atas

2. Rp. 500 Juta s/d Rp. 5 milyar

3. Rp. 50 Juta s/d Rp. 500 Juta

4. Rp. 0 s/d Rp. 50 Juta (mikro) bahkan menjadi 8,9\% (termasuk "credit card" yang rata-rata pemiliknya bukan usaha mikro)

Dapat disimpulkan bahwa 99,9\% entitas pengusaha hanya mendapatkan fasilitas 8,9\%. Padahal sektor ekonomi mikro informal sangat besar dalam memainkan perannya pada aktivitas ekonomi di negara berkembang. Selain itu, disinyalir keterpurukan ekonomi di negara berkembang disebabkan ketidakmampuan untuk menumbuhkan Lembaga Permodalan yang khas bagi masyarakatnya yang mayoritas pengusaha mikro informal (Aziz, 2008; 12).

Alasan kedua mengapa BMT memiliki peran yang sangat strategis adalah alasan momentum. Yang diantaranya adalah :

- Millenium Development Goals (MDGs), strategi menurunkan 50\% dari 1,3 milyar jumlah penduduk miskin dunia hingga 2015 melalui pendekatan keuangan mikro;

- Pencanangan The International Micro Finance Year pada tanggal 18 Nopember 2004 di New York oleh Sekjen PBB Kofi Anan;

- Pencanangan Tahun Keuangan Mikro Indonesia oleh Presiden Susilo Bambang Yudhoyono pada tanggal 26 Pebruari 2005 di Jakarta dan menargetkan penurunan rakyat miskin 50\% pada tahun 2015.

Kemudian alasan ketiga adalah alasan potensi. Dari hasil penelitian UIN Syarif Hidayatullah Jakarta, potensi umat Islam untuk "Dana Sosial" / Baytul Maal di Indonesia tidak kurang dari 19 Triliun per tahun, sementara yang bisa dikonsolidasi melalui lembaga sosial Islam sekitar 500 
miliar per tahun. Kemudian potensi umat untuk "Tabungan" / Baytul Tamwil (LKM) : ilustrasi data BRI : Simpedes 24 T (2002), 57 T (2005), Kupedes 12 T (2002) dan 27 T (2005). Artinya rakyat di pedesaan pun memiliki potensi dana yang jauh lebih besar dari dayaserap pinjamannya.

Selain itu terdapat potensi perkuatan melalui "Sinergi Program" Pemerintah : PNPM Mandiri, Kementerian Tenagakerja dan Transmigrasi (Penanggulangan Pengangguran, BMT Trans, LKM Tabung Tani), Kementerian Sosial (LKM/ BMT KUBE), Kementerian Pertanian (LKM/ BMT Agribisnis, PUAP), Kementerian Koperasi dan UKM (P3KUM melalui KJKS/ BMT), Kementerian Perumahan Rakyat (KPRS melalui BMT), Kementerian Kehutanan (Pemberdy. Masy. Pinggiran Hutan melalui Pengembangan BMT), Kementerian Kelautan dan Perikanan (PEMP Pola LEPM3 Syariah/ BMT), BUMN (PKBL), dan sebagainya. Dan juga potensi "Linkage" pembiayaan dari Perbankan Syariah, Islamic Development Bank (IDB), dan sebagainya.

Sedangkan alasan keempat yaitu alasan sejarah. Baytul maal sudah ada sejak zaman nabi dan mulai dilembagakan pada masa Khalifah Umar atas nasehat Walid Bin Hisyam. Baytul maal adalah pos khusus harta kaum muslimin untuk penyelenggaraan pemerintahan \& kesejahteraan umat. Sumber baytul maal adalah fai', ghanimah, anfal, kharaj, jizyah, dan pemasukan milik umum, milik negara, usyur, khumus, rikaz, tambang, serta zakat. Namun baitul dalam BMT saat ini membatasi hanya pada pendayagunaan ZISWAF. Selain itu sistem bagi hasil sudah membudaya pada praktik pertanian dan peternakan masyarakat Indonesia.

Alasan terakhir yaitu alasan ideologis. Indonesia sebagai negara dengan penduduk muslim terbanyak saat ini perekonomiannya belum terlalu membaik. Padahal Islam sebagai agama yang sempurna telah memberikan solusi yang jelas. Semua aturan tersebut sudah ada dan kita hanya perlu mempraktikannya saja.

Beberapa fakta lain yang mendukung yaitu, pertumbuhan Lembaga Keuangan Mikro Syariah (LKMS) dari tahun ke tahun terus meningkat. Secara kelembagaan, sekarang sudah ada sekitar 4.000 LKMS/ BMT. Mereka mengelola aset sekitar Rp 3 triliun rupiah (Jularso, 2010). Menurut data Kemenkop dan UKM, total Koperasi Simpan Pinjam (KSP)/ Usaha Simpan Pinjam (USP), koperasi dan koperasi kredit di Indonesia sebanyak 71.365 unit. Dari jumlah itu, sebanyak 2.508 unit merupakan Koperasi Jasa keuangan Syariah (KJKS) / Usaha Jasa Keuangan Syariah (UJKS). Total aset KJKS/ UJKS ini mencapai Rp 13,23 triliun. Padahal, total aset KSP sendiri hanya Rp 18,72 triliun. Walaupun jumlah BMT hanya 3,7\% dari seluruh koperasi simpan pinjam yang ada, namun ternyata total asetnya mencapai 70,67\% dari total aset koperasi simpan pinjam. Hal ini semakin memperkuat betapa strategisnya peran BMT di Indonesia.

Akan tetapi di sisi lain fakta di lapangan menunjukkan beberapa BMT rugi dan bubar. Sebagai contoh, pada tahun 2000 di Kabupaten Ciamis jumlah BMT mencapai 42 unit, namun sekarang hanya tersisa 7 unit. Di daerah Tasikmalaya yang pernah mencapai 50 BMT lebih, kini hanya tersisa 12 unit. Begitu juga di Kabupaten Garut dan Sumedang yang kondisinya tidak jauh berbeda dengan yang terjadi di Tasikmalaya dan Ciamis. Hal serupa juga terjadi di kota Bandung, keberadaan BMT sebagai badan penunjang dana bagi masyarakat ekonomi lemah terancam bangkrut. Dari 32 BMT, kini jumlahnya makin menciut dan tinggal 8 unit yang masih beroperasi(Sumiyanto, 2008).

Beberapa penyebab tidak sustainnya BMT di Indonesia adalah manajemen yang buruk, pengelola yang tidak amanah, sumberdaya manusia yang tidak mampu bekerja secara profesional, tidak dapat menarik kepercayaan masyarakat, kesulitan modal dan seterusnya (Sumiyanto, 2008). 
Oleh karena itu dengan diketahuinya permasalahan BMT maka BMT akan lebih berkembang dengan pesat, karena permasalahan-permasalahan yang ada sudah terpetakan dengan baik. Pada akhirnya, penyelesaian permasalahan akan lebih terorganisir dan BMT dapat memberikan kontribusi yang lebih besar kepada perekonomian dan kesejahteraan umat Indonesia.

\section{Konsep Dasar Islam}

Islam memandang bahwa bumi dan segala isinya merupakan amanah Allah kepada sang khalifah agar dipergunakan sebaik-baiknya bagi kesejahteraan bersama. Untuk mencapai tujuan ini, Allah memberikan petunjuk melalui para RasulNya. Petunjuk tersebut meliputi segala sesuatu yang dibutuhkan manusia baik akidah, akhlak, maupun syariah.

Dua komponen pertama akidah dan akhlak, bersifat konstan. Keduanya tidak mengalami perubahan apapun dengan berbedanya waktu dan tempat. Adapun syariah senantiasa berubah sesuai dengan kebutuhan dan taraf peradaban umat, yang berbeda-beda sesuai dengan masa rasul masing-masing. Hal ini diungkapkan dalam Al-Qur'an: "Untuk tiap-tiap umat diantara kamul $^{l}$, Kami berikan aturan dan jalan yang terang”". (QS. Al-Maidah: 48)

Juga Rasulullah SAW bersabda dalam suatu hadits,

"Para Rasul tak ubahnya sebagai saudara sebapak, ibunya (syariahnya) berbeda-beda sedangkan dinnya (tauhidnya) satu." (HR Bukhari, Abu Dawud, dan Ahmad).

Oleh karena itu, syariah Islam sebagai suatu syariah yang dibawa oleh rasul terakhir, mempunyai keunikan tersendiri. Syariah ini bukan saja menyeluruh atau komprehensif tetapi juga universal. Karakter ini diperlukan sebab tidak akan ada syariah lain yang datang untuk menyempurnakannya.

Komprehensif berarti syariah Islam merangkum seluruh aspek kehidupan, baik ritual (ibadah) maupun sosial (muamalah). Ibadah diperlukan untuk menjaga ketaatan dan keharmonisan hubungan manusia dengan khaliqnya. Ibadah juga merupakan sarana untuk mengingatkan secara berkesinambungan tugas manusia sebagai khalifah-Nya di muka bumi ini. Adapun muamalah diturunkan untuk menjadi aturan main manusia dalam kehidupan sosial. Kelengkapan sistem muamalah yang disampaikan Rasulullah SAW, terangkum pada gambar 1. Universal bermakna syariah Islam dapat diterapkan dalam setiap waktu dan tempat sampai hari akhir nanti. Universalitas ini tampak jelas terutama pada bidang muamalah. Selain mempunyai cakupan luas dan fleksibel, muamalah tidak membedakan antara muslim dan nonmuslim.

Sifat muamalah ini dimungkinkan karena Islam mengenal hal yang diistilahkan sebagai tsawabit wa mutaghayyirat (prinsip dan variabel) Dalam sektor ekonomi, misalnya, yang merupakan prinsip adalah larangan riba, sistem bagi hasil, pengambilan keuntungan, pengenaan zakat, dan lain-lain. Adapun contoh variabel adalah instrumen-instrumen untuk melaksanakan prinsipprinsip tersebut. Diantaranya adalah aplikasi prinsip jual beli dalam modal kerja, penerapan asas mudharabah dalam investasi atau penerapan bai' as-salam dalam suatu proyek. Tugas cendekiawan muslim sepanjang zaman adalah mengembangkan teknik penerapan prinsipprinsip tersebut dalam variabel-variabel yang sesuai dengan situasi dan kondisi pada setiap masa.

\footnotetext{
${ }^{1}$ Maksudnya: umat Nabi Muhammad s.a.w. dan umat-umat yang sebelumnya
} 


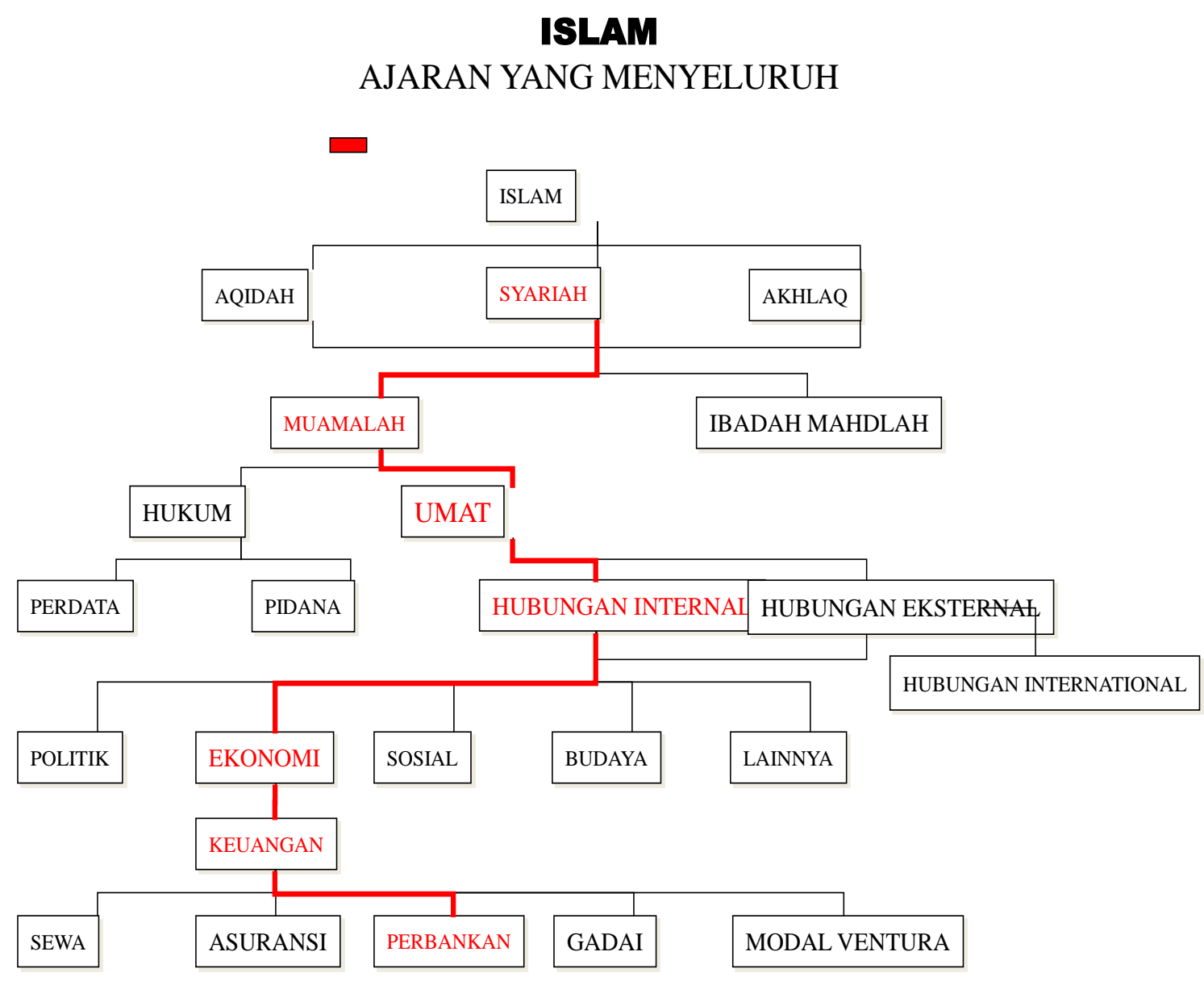

Diolah dari Antonio, 2001

Gambar 1 Komprehensivitas Ajaran Islam 


\section{Solusi Peningkatan Sumberdaya Manusia pada BMT Melalui Pendekatan Analytic Network Process atau ANP}

Analytic Network Process atau ANP adalah alat analisis yang memungkinkan kita menghadapi faktor-faktor dependence serta feedbacknya secara sistematik. Dalam bahasa lain, ANP merupakan satu dari metode Multiple Criteria Decision Making (MCDM) yang dikembangkan oleh Thomas L Saaty.

Metode ini merupakan pendekatan baru metode kualitatif yang merupakan perkembangan lanjutan dari metode terdahulu yakni Analytic Hierarchy Process (AHP). Kelebihan ANP dari metodologi yang lain adalah kemampuannya untuk membantu kita dalam melakukan pengukuran dan sintesis sejumlah faktor-faktor dalam hierarki atau jaringan.

Banyak kelebihan dari metode baru yang diperkenalkan oleh Saaty ini . anatara lain adalah kesederhanaan konsep yang ditawarkan. Dari kesederhanaan metodologinya membuat ANP menjadi metodologi yang lebih umum dan lebih mudah diaplikasikan untuk studi kualitatif yang beragam, seperti pengambilan keputusan, forecasting, evaluasi, mapping, strategizing, alokasi sumberdaya dan lain sebagainya. Jika dikaji lebih lanjut, tidak ada metodologi lain yang mempunyai fasilitas sintesis seperti metodologi ANP (Saaty, 2005).

Jika dibandingkan dengan metodologi AHP, ANP memiliki banyak kelebihan, seperti komparasi yang lebih objektif, prediksi yang lebih akurat, dan hasil yang lebih stabil dan robust. ANP lebih bersifat umum dari AHP yang digunakan di multi-criteria decision analysis. Struktur AHP merupakan suatu decision problem dalam bentuk tingkatan suatu hirarki, sementara ANP menggunakan pendekatan jaringan tanpa harus menetapkan level seperti pada hierarki yang digunakan dalam AHP (Saaty, 2005).

ANP digunakan untuk memecahkan masalah yang bergantung pada alternatif-alternatif dan kriteria-kriteria yang ada. Dalam teknik analisisnya, ANP menggunakan perbandingan berpasangan pada alternatif-alternatif dan kriteria proyek. Pada jaringan AHP terdapat level tujuan, kriteria, subkriteria, dan alternatif, dimana masing-masing level memiliki elemen. Sementara itu, pada jaringan ANP, level dalam AHP disebut cluster yang dapat memiliki kriteria dan alternatif didalamnya, yang sekarang disebut simpul:

Dengan feedback, alternatif-alternatif dapat bergantung/ terikat pada kriteria seperti pada hierarki. Tetapi dapat juga bergantung/ terikat pada sesama alternatif. Lebih jauh lagi, kriteriakriteria itu sendiri dapat tergantung pada alternatif-alternatif dan pada sesama kriteria.

Sementara itu, feedback meningkatkan prioritas yang diturunkan dari judgments dan membuat prediksi menjadi lebih akurat. Oleh karena itu, hasil dari ANP diperkirakan akan lebih stabil dari jaringan feedback. Pada gambar 2 di atas dapat dilihat bahwa simpul atau elemen utama dan simpul-simpul yang akan dibandingkan dapat berada pada cluster-cluster yang berbeda. Sebagai contoh, ada hubungan langsung dari simpul utama C4 ke cluster lain (C2 dan C3), yang merupakan outer dependence. Sementara itu, ada simpul utama dan simpul-simpul yang akan dibandingkan berada pada cluster yang sama, sehingga cluster ini terhubung dengan dirinya sendiri dan membentuk hubungan loop. Hal ini disebut inner dependence (Ascarya, 2005).

Yang diinginkan dalam ANP adalah mengetahui keseluruhan pengaruh dari setiap elemen. Oleh karena itu, semua kriteria harus diatur dan dibuat prioritas dalam suatu kerangka kerja hierarki kontrol atau jaringan, melakukan perbandingan dan sintesis untuk memperoleh urutan prioritas dari sekumpulan kriteria ini. kemudian kita turunkan pengaruh dari elemen dalam feedback dengan memperhatikan masing-masing kriteria.

Akhirnya, hasil dari pengaruh ini dibobot dengan tingkat kepentingan dari kriteria, dan ditambahkan untuk memperoleh pengaruh keseluruhan dari masing-masing elemen (Ascarya, 2005). Alasan keberhasilan metode ini adalah cara memperoleh keputusan dan menggunakan perhitungan untuk mendapat skala rasio.

Di sini pula letak kekuatan dari ANP yaitu 
adanya penggunaan skala rasio untuk mendapatkan semua jenis interaksi dan mengakuratkan prediksi untuk memperoleh keputusan terbaik. Prioritas sebagai skala rasio adalah sesuatu hal yang mendasar dari angka untuk mengadakan perhitungan aritmatika dasar dengan menambahkannya dalam skala yang sama serta mengalikannya dengan skala yang berbeda yang berarti bagi ANP.

\subsection{Prinsip Dasar ANP}

Ada tiga prinsip dasar dalam AHP/ANP, yakni dekompoisi, penilaian komparasi, dan komposisi hirarki (sintesis) (Saaty, 1994 dalam Ascarya, 2006):

1) Prinsip dari dekomposisi adalah diterapkan untuk menstruktur masalah yang kompleks ke dalam suatu hirarki atau jaringan cluster-cluster, sub cluster, dan sebagainya. Dengan kata lain, dekomposisi mencoba untuk memodelkan masalah ke dalam bingkai AHP/ANP.

2) Penilaian komparasi. Prinsip dari penilaian komparasi ini adalah diterapkan untuk membangun perbandingan pairwise (pasangan) dari semua kombinasi-kombinasi dari elemen-elemen dalam suatu cluster dengan dilihat dari cluster induknya. Semua pasangan perbandingan itu digunakan untuk mendapatkan prioritas 'lokal' elemenelemen dalam suatu cluster dengan dilihat dari induknya.

3) Komposisi Hirarki atau Sintesis.

Prinsip dari komposisi hirarki atau sintesis diterapkan untuk mengalihkan prioritas lokal elemen-elemen dalam suatu cluster dengan prioritas 'global' dari elemen induk, yang akan menghasilkan prioritas global dari seluruh hirarki atau jaringan dan lalu menambahkan prioritas global untuk elemen-elemen pada level terendah (biasanya adalah alternatif-alternatif).

\subsection{Fungsi Utama ANP}

Ada tiga fungsi utama ANP, yaitu (Ascarya, 2005):

1) Menstruktur kompleksitas.

Yaitu dengan menstruktur kompleksitas secara hirarkis ke dalam cluster-cluster yang homogen dari faktor-faktor.

2) Pengukuran ke dalam skala rasio.

Pengukuran dalam skala rasio ini diperlukan untuk mencerminkan proporsi. Setiap metodologi dengan struktur hierarki harus menggunakan prioritas skala rasio untuk elemen di atas level terendah dari hierarki. Hal ini penting karena prioritas (atau bobot) dari elemen di level manapun dari hierarki ditentukan dengan mengalikan prioritas dari elemen induknya. Karena hasil perkalian dari dua pengukuran level interval secara matematis tidak memiliki arti, skala rasio diperlukan untuk perkalian ini. AHP/ANP menggunakan skala rasio pada semua level terendah dari hierarki/jaringan, termasuk level terendah (alternatif dalam model pilihan). Skala rasio ini menjadi semakin penting jika prioritas tidak hanya digunakan untuk aplikasi pilihan, namun untuk aplikasiaplikasi lain, seperti untuk aplikasi alokasi sumberdaya. 
3) Sintesis.

Sintesis berarti menyatukan semua bagian menjadi satu kesatuan. Karena kompleksitas, situasi keputusan penting, atau prakiraan, atau alokasi sumberdaya, sering melibatkan terlalu banyak dimensi bagi manusia untuk dapat melakukn sintesis secara intuitif, kita memerlukan suatu cara untuk melakukan sintesis dari banyak dimensi. Fungsi yang lebih penting lagi dalam AHP/ANP adalah kemampuannya untuk membantuk kita dalam melakukan pengukuran dan sintesis sejumlah faktor-faktor dalam hierarki atau jaringan. Tidak ada metodologi lain yang mempunyai fasilitas sintesis seperti AHP/ANP.

\section{Solusi Internal Sumberdaya Manusia BMT}

\subsection{Pelatihan dan Workshop}

Berdasarkan hasil olah data, pelatihan yang cukup dan lengkap meliputi teori dan praktik merupakan salah satu faktor keberhasilan BMT. Dengan adanya pelatihan dan workshop maka pengetahuan dan skill dari pengurus dan pengelola akan meningkat. Peningkatan skill dan pengetahuan pada akhirnya akan meningkatkan produktifitas dari SdM BMT.

\subsection{Seleksi Sumberdaya Manusia (SdM)}

Perlu adanya penyeleksian pegawai BMT yang tidak hanya capable dalam hal manajemen keuangan secara konvensional saja, akan tetapi juga memikirkan maslahah untuk mencapa falah. Dalam hal ini SdM BMT memiliki beberapa kemampuan yaitu:

- Kemampuan marketing,

- Kemampuan analisa pembiayaan,

- Konsultan usaha, karena BMT bukan menjual uang tetapi mengikuti bisnis,

- Kemampuan pendampingan,

- Juru dakwah.

\subsection{Insentif}

Pegawai yang berprestasi dan memberikan kontribusi positif perlu mendapatkan insentif. Dengan adanya insentif, secara tidak langsung akan berdampak pada motivasi etos kerja untuk bekerja lebih baik.

\subsection{Peningkatan Ibadah}

Peningkatan ibadah merupakan hal yang penting untuk meningkatkan ruhiyah. Karena beberapa praktisi dan pakar mengatakan bahwa ruhiyah yang kuat merupakan hal yang sangat dibutuhkan pada setiap fase perkembangan BMT. Didirikannya BMT itu sendiri berorientasi pada landasan niat untuk beribadah kepada Allah SWT melalui penguatan ekonomi dan perbaikan kualitas hidup umat (Aziz, 2008).

\section{$5 \quad$ Analisis Strategi}

Berdasarkan gambar 2 di bawah ini, dapat dilihat bahwa dua strategi utama untuk menyelesaikan permasalahan-permasalahan BMT adalah standarisasi SdM dan sistem training edukasi, serta membangun infrastruktur dan fasilitas. Standarisasi SdM dan sistem training edukasi menempati urutan pertama (0.41), hal itu sesuai dengan hasil analisis permasalahan 
internal dan solusinya bahwa permasalahan dan solusi SdM merupakan prioritas utama, karena SdM yang berkualitas merupakan tonggak utama keberhasilan BMT. SdM berkualitas bukan hanya dari profesionalitas saja, akan tetapi yang lebih penting lagi adalah mempunyai pemahaman yang mendalam mengenai pengetahuan syariah muamalah.

Kemudian prioritas kedua dengan selisih prioritas yang tidak signifikan yaitu pembangunan infrastruktur dan fasilitas $(0,38)$. Sudah saatnya BMT mendapatkan perhatian dari pemerintah mengingat perannya yang begitu besar. Besar harapan dari para praktisi BMT akan adanya dukungan dari pemerintah melalui pembangunan fasilitas dan infrastruktur BMT.

Adapun strategi membentuk wadah sosialisasi yang efektif menempati prioritas yang ketiga $(0,15)$ dan dibentuknya jurusan Islamic Micro Finance pada tingkat perguruan tinggi menjadi prioritas terakhir $(0,06)$. Sedangkan tingkat kesepakatan antarrater sangat tinggi ditunjukkan dengan nilai $\mathrm{W}$ sebesar $(0,91)$. Hal ini menunjukkan bahwa seluruh responden bersepakat bahwa dua strategi utama yang harus dilakukan untuk menangani berbagai permasalahan BMT adalah standarisasi SdM dan sistem training edukasi, serta membangun infrastruktur dan fasilitas.

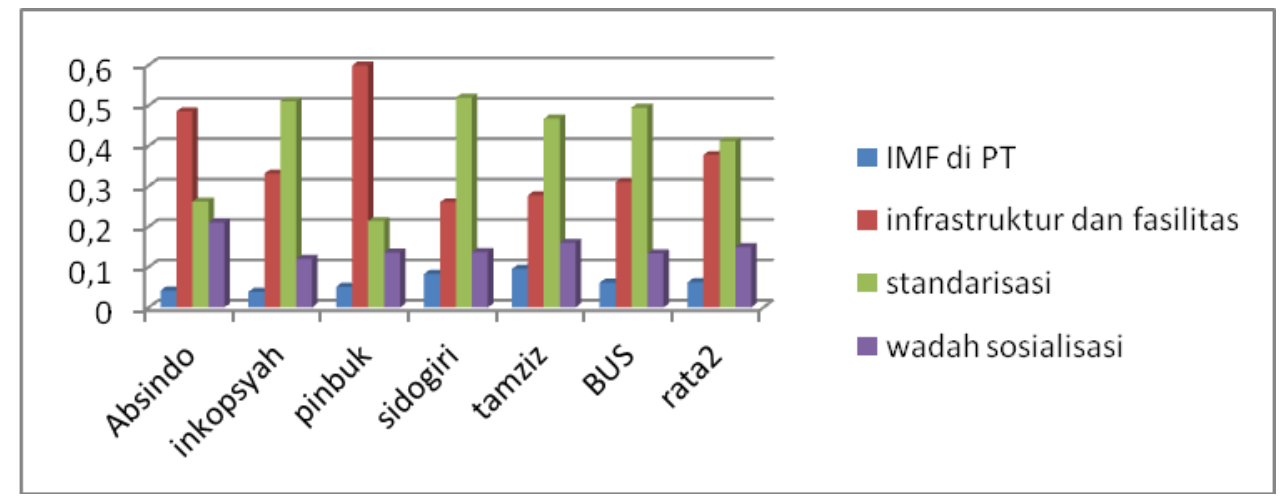

Gambar 2 Hasil ANP berdasarkan Cluster Strategi

\section{Kesimpulan dan Saran}

Berdasarkan pembahasan dan analisa permasalahan internal BMT, berikut dapat ditarik beberapa kesimpulan mengenai pembahasan ini, diantaranya adalah:

1. Berdasarkan hasil penelitian menunjukkan bahwa permasalahan BMT dibagi menjadi dua aspek utama, internal dan eksternal. Permasalahan internal terbagi menjadi tiga permasalahan yaitu internal BMT, teknis pengelolaan dan SdM. juga terbagi menjadi tiga bagian yaitu masyarakat, otoritas dan $\mathrm{p}$ embiayaan alternatif. Secara lebih rinci dapat dilihat pada kerangka penelitian diatas.

2. Masalah internal yang menjadi masalah utama adalah $\operatorname{SdM}(0,61)$. Angka prioritas tersebut menunjukkan bahwa permasalah utama pada internal BMT adalah permasalahan SdM. Permasalahan SdM pada BMT sangat mendesak untuk diselesaikan.

3. Sejalan dengan masalah, maka solusi yang lebih diprioritaskan berdasarkan aspek internal adalah solusi SdM $(0,60)$. Angka tersebut menunjukkan bahwa solusi utama yang perlu untuk dilaksanakan adalah solusi SdM. Jika dilihat lebih rinci maka terdapat tiga permasalahan prioritas yang perlu di selesaikan yaitu penerapan teknologi, seleksi SdM dan konsistensi. Penerapan teknologi terdapat pada cluster teknis pengelolaan yang merupakan prioritas kedua, namun ternyata penerapan teknologi memiliki prioritas yang lebih utama 
dibandingkan solusi SdM satu per satu secara keseluruhan. Begitu juga dengan solusi konsistensi yang merupakan bagian dari cluster solusi internal BMT. Konsistensi para SdM sendiri merupakan salah satu kunci sukses dari seluruh BMT yang menjadi responden penulis.

4. Strategi yang dapat dilakukan untuk mengatasi permasalahan internal dan eksternal BMT sesuai dengan urutan prioritas adalah melalui standarisasi SdM dan sistem training edukasi menempati urutan pertama (0.41).

Berdasarkan hasil pembahasan, ada beberapa saran yang dapat penulis rekomendasikan, diantaranya adalah:

1. BMT seyogyanya senantiasa meningkatkan dan memperhatikan kualitas SdM-nya, tidak hanya pada sisi profesionalitasnya tetapi juga pada komitmen dan pengetahuan syariah muamalahnya. Selain itu peningkatan keimanan dan ketakwaan serta ibadah dari SdM juga perlu untuk konsisten dilaksanakan. Hal itu mengingat hasil penelitian yang menunjukkan betapa pentingnya permasalahan SdM pada BMT.

2. Bagi pemerintah hendaknya turut memiliki andil dan mendukung dalam pengembangan BMT melalui kebijakan-kebijakannya. Mengingat penelitian yang penulis lakukan menunjukkan bahwa pembuatan kebijakan merupakan solusi yang paling prioritas dari seluruh permasalahan eksternal BMT. Pembangunan infrastruktur dan fasilitas juga perlu pemerintah lakukan mengingat strategisnya peran dari BMT.

3. Baik dari pemerintah, pakar, praktisi BMT, maupun akademisi hendaknya melakukan strategi program sosialisasi, edukasi dan komunikasi kepada masyarakat. Program ini dapat dilakukan oleh siapa saja, baik itu dari pihak eksternal dan internal, sehingga melalui program ini akan turut mendukung penyelesaian salah satu permasalahan krusial yaitu kurangnya pemahaman masyarakat terhadap praktik syariah muamalah yang diterapkan oleh BMT. 


\section{Daftar Pustaka}

Afandi, Yazid ,2011, Mendialogkan Konsep Ideal BMT dan Realitas Masyarakat, Yogyakarta : LOS DIY.

Ahmed, Salehuddin, 2009, Microfinance Institutions In Bangladesh: Achievements And Challenges, International Journal Of Islamic And Middle Eastern Finance And Management Vol 35 No 12, Emerald Grup Publishing Limited.

Al Jauziyah, IbnulQayyim, $A d d a^{\prime}$ wad Dawa, Jakarta : Pustaka Imam Syafii

Ascarya, "Analytic Network Process (ANP): Pendekatan baru studi kualitatif", Makalah pada seminar intern program Magister Akuntansi fakultas Ekonomi di Universitas Trisakti, Jakarta,2005.

Aswin, Ikswan (2008), Jumlah UMKM Membengkak Tahun 2009. Hotml 25 Agustus 2009.

Aziz, Amin, 2008, Panduan Pendirian BMT, Jakarta : PKES Publishing.

, 2000, Prospek BMT Berbadan Bukum Koperasi, Jakarta : Pinbuk.

Badan Pusat Statistik (2008), Berita Resmi Statistik BPS: Perkembangan Indikator Makro UKM Tahun 2008, Jakarta: BPS.

Choudury, Masudul Alam Dkk, 2008, A Well-Being Model Of Small Scale Microenterprise Development To Alleviate Poverty A Case Study Of Bangladesh Village, International Journal Of Islamic And Middle Eastern Finance And Management Vol 28 No 11/12, Emerald Grup Publishing Limited.

Dusuki, Asyraf Wajdi, 2008, Banking For The Poor: The Role Of Islamic Banking In Microfinance Initiatives, International Journal Of Islamic And Middle Eastern Finance And Management Vol 24 No 1, Emerald Grup Publishing Limited.

Hadisumarto, Widiyanto Bin Mislan Cokro dan Ismail, Abdul Ghafar B, 2010, Improving The Effectiveness Of Islamic Micro-Financing Learning From BMT Experience, International Journal Of Islamic And Middle Eastern Finance And Management Vol 26 No 1, Emerald Grup Publishing Limited.

Haque, Marissa Grace ,2011, Analisis Strategi LKM Syariah nonbank, Yogyakarta : LOS DIY.

Hasibuan, Syahbenol ,2011, Telaah Hukum dan Penyelesaian masalah BMT, Yogyakarta : LOS DIY.

Karim, Adiwarman ,2008, Ekonomi Mikro Islami, Jakarta: PT. Raja Grafindo Persada.

Kuncoro, Mudrajad ,2011, Urgensi Regulasi BMT: Antara Syariah dan Koperasi, Yogyakarta: LOS DIY.

Muftie, Aries ,2011, Apex BMT Menuju Kemandirian BMT. Yogyakarta: LOS DIY.

Muhammad, 2011, Konsep Syariah dalam Operasional BMT, Yogyakarta : LOS DIY.

Perwataatmadja, Karnaen A dan Hendri Tanjung ,2007, Bank Syariah : Teori, Praktik dan Peranannya, Jakarta : Celestial Publishing.

Pramono, Ananta Heri, 2011, BMT Etis, Berbuah Manis, Yogyakarta : LOS DIY.

Pusat Pengkajian dan Pengembangan Ekonomi Islam (P3EI) Universitas Islam Indonesia Yogyakarta dan Bank Indonesia, 2008, "Ekonomi Islam", Jakarta : PT Rajagrafindo Persada

Rahman, M. Mizanur dan Fariduddin Ahmad, 2010, Impact Of Microfinance Of IBBL On The Rural Poor's Livelihood In Bangladesh: An Empirical Study, International Journal Of Islamic And Middle Eastern Finance And Management Vol 3 No 2, Emerald Grup Publishing Limited.

Rambe, Mursida ,2011, Peranan Strategis BMT dalam Menyejahterakan Umat, Yogyakarta : LOS DIY.

Ridwan, 2011, Pengawasan Syariah dalam Pengelolaan BMT. Yogyakarta : LOS DIY.

Ridwan, Muhammad (2004). Manajemen Baitul maal wa Tamwil (BMT), $\quad$ Yogyakarta: UII Press. 
Saaty, Thomas L dan Vargas, 2006, Decision Making with the Analytic Network Process, Pittsburgh: University of Pittsburgh.

2005, Theory and Applications of the Analytic Network Process, Pittsburgh: University of Pittsburgh.

Sudikno, Astungkoro ,2011, Audit Asset BMT dan Penegakan Soko Guru Perekonomian, Yogyakarta. LOS DIY.

Syafi'i, Antonio, 2001, Bank Syariah : dari Teori ke Praktik, Jakarta : Gema Insani Press.

Syaflan, Meidi ,2011, Model Governance BMT: Perspektif Sejarah dan Praktis, Yogyakarta : LOS DIY.

Vogel, Frank E dan Samuel L. Hayes III, 2007, Hukum Keuangan Islam : Konsep, Teori, dan Praktik, Bandung :Nusamedia.

Wafa, Muhammad Agus dan Nasrodin ,2008, Baitul maal Wa At-Tamwil, Tugas, tidak diterbitkan.

Zuhri, Bachrul Ulum ,2011, Strategi Bisnis dan Sosial BMT, Yogyakarta: LOS DIY. 